Original Article

\title{
Effect of aqueous extract of Moringa oleifera leaves on pharmacological models of epilepsy and anxiety in mice
}

\author{
Suvarna P. Ingale*, Foram P. Gandhi \\ SCES's Indira College of Pharmacy, Pune 411033, India
}

\section{A R T I C L E I N F O}

\section{Article history:}

Received 28 September 2015

Accepted 3 February 2016

Available online 4 March 2016

Keywords:

Anxiety

Epilepsy

GABA

Baclofen

Moringa oleifera

\begin{abstract}
A B S T R A C T
Objective: Among the psychiatric co-morbidities in epilepsy, anxiety disorders are highly frequent and have profound influence on the quality of life of epilepsy patients. Moringa oleifera Lam. (Moringaceae) is used in traditional medicine to treat various ailments including anxiety and epilepsy. However, no scientific evidence exists to support its use. We studied antiepileptic and anxiolytic activities of aqueous extract of Moringa oleifera Lam. leaves (AEMO).

Methods: Antiepileptic activity was evaluated using pentylenetetrazole (PTZ) induced seizure and maximum electroshock (MES) induced seizure test and anxiolytic activity was evaluated using elevated plus maze, light/dark box and hole board test.

Results: In present study, AEMO (250, 375 and $500 \mathrm{mg} / \mathrm{kg}$, i.p.) demonstrated significant antiepileptic and anxiolytic effects. To study involvement of GABA in anxiolytic and antiepileptic activity of AEMO, we also evaluated effect of AEMO on Baclofen induced catatonia, a GABA mediated behavior, wherein AEMO significantly potentiated (preponed) baclofen induced catatonia, which is suggestive of its GABA mimetic action.

Conclusion: Thus, it may be concluded that aqueous extract of $M$. oleifera possess anxiolytic and antiepileptic effects possibly mediated via of GABA mimetic action and these findings authenticate the traditional claims about use of Moringa oleifera in treatment of epilepsy and anxiety.
\end{abstract}

(C) 2016 Indian Epilepsy Society. Published by Elsevier, a division of Reed Elsevier India, Pvt. Ltd. All rights reserved.

\section{Introduction}

Epilepsy is a group of chronic neurological disorders characterized by seizures, which are the result of abnormal, excessive or hypersynchronous neuronal activity in the brain. Epilepsy is a worldwide problem that affects between $2 \%$ and $3 \%$ of the population and accounts for $0.5 \%$ of the global burden of disease. According to WHO, epilepsy is one of the most common neurological diseases globally, as approximately 50

\footnotetext{
* Corresponding author at: Department of Pharmacology, SCES's Indira College of Pharmacy, New Pune-Mumbai Highway, Tathawade, Pune 411033, India. Tel.: +91 9423219990.

E-mail address: suvarnaingale@gmail.com (S.P. Ingale).

http://dx.doi.org/10.1016/j.ijep.2016.02.001

2213-6320/C 2016 Indian Epilepsy Society. Published by Elsevier, a division of Reed Elsevier India, Pvt. Ltd. All rights reserved.
} 
million people worldwide have epilepsy. Epidemiological studies show that psychiatric disorders are more prevalent among people with epilepsy than in the general population. The existence of comorbid psychiatric disorders has a significant impact on the treatment of epilepsy. ${ }^{1}$ Among the psychiatric co-morbidities in epilepsy, anxiety disorders are highly frequent and have a profound influence on the quality of life of epilepsy patients. Several studies have reported elevated rates of panic attacks, panic disorder, obsessive compulsive disorder (OCD), social anxiety disorder and generalized anxiety disorder (GAD) in adult patients with epilepsy as compared with the general population. ${ }^{2}$ Anxiety is defined as a feeling of apprehension, uncertainty or tension stemming from the anticipation of imagined or unreal threat. $^{3}$ Anxiety affects $1 / 8$ th population worldwide and has become an important research area in - the field of psychopharmacology. ${ }^{4}$

There is a complex relationship between anxiety and epilepsy like - anxiety as a reaction to a diagnosis of epilepsy, anxiety as a response to social and family stigma due to epilepsy, anxiety as an epileptic aura, ictal anxiety, anxiety (agitation), which occurs during epileptic psychosis, real phobic anxiety related to the attack and anxiety that precipitates an attack. ${ }^{5}$ Thus, there is need to come up with the drug therapy useful in the treatment of epilepsy as well as anxiety, which will improve quality of life in epileptic patients.

Moringa oleifera Lam. (Family: Moringaceae) is commonly known as drumstick tree or Shevga. Different parts of these plants are being employed for the treatment of various ailments in the indigenous system of medicine. Several bioactive compounds were recognized in the leaves of $M$. oleifera such as vitamins, carotenoids, polyphenol, phenolic acids, flavonoids, alkaloids, glucosinolates, isothiocyanates, tannins, saponins and oxalates and phytates. The leaves are rich in Vitamin A and C. It also contains Niazirin, Niazirinin, three mustard oil glycosides, 4-[(4'-O acetylalpha-L-rhamnosyloxy) benzyl]isothiocyanate, Pyrrole alkaloid (pyrrolemarumine 400O-a-L-rhamnopyranoside), and 40-hydroxyphenylethanamide (marumosides A and B), $\alpha$ and $\gamma$-tocopherol.

It possess antitumor, antipyretic, anti inflammatory, antiulcer, antispasmodic, diuretic, antihypertensive, antidiabetic and hepatoprotective activities. ${ }^{6,7}$ Traditional claims about M. oleifera Lam. suggest its potential in treatment of epilepsy and anxiety. ${ }^{8,9}$ There was no scientific reports presented on the antiepileptic and anxiolytic activity of aqueous extract of Moringa oleifera Lam. leaves (AEMO). Hence, the present study is designed to validate the uses of $\mathrm{M}$. oleifera Lam. leaves in epilepsy and anxiety.

\section{Materials and methods}

\subsection{Plant material}

The fresh leaves of M. oleifera Lam. were collected in the month of March and authenticated by Dr. J. Jayanthi, Botanical Survey of India, Pune-411001. The voucher specimen of the same was deposited in Botanical Survey of India, Pune. (Voucher Specimen No: FOGMO3).

\subsection{Preparation of extract}

Fresh leaves of M. oleifera Lam. were shade dried. Shade dried powdered leaves $(1 \mathrm{~kg}$ ) mixed with boiling water and macerated for $2 \mathrm{~h}$. Process is continued by gradually adding boiling water until extraction process was completed. The aqueous extract was filtered, concentrated by evaporation on hot water bath. The finally obtained extract was weighed; and stored in cool place (Yield $=22.7 \%$ ). After qualitative and quantitative chemical investigation, the aqueous extract of Moringa oleifera leaves (AEMO) was used for pharmacological studies (Rathi et al., 2006).

\subsection{Drugs and chemicals}

Baclofen, Diazepam, and Phenytoin were obtained from Alkem Laboratories Ltd, Nacharam, Hyderabad.

\subsection{Animals}

Swiss Albino mice weighing 20-25 g of either sex were used. The animals were maintained under standard laboratory conditions at temperature $24 \pm 2{ }^{\circ} \mathrm{C}$ and relative humidity (30-70\%) with a 12:12 h light:dark cycle throughout all the experiment. The animals were fed with standard pellet diet and free access of water. The animals were shifted to the laboratory one hour prior to the experiment. All the experimental procedures and protocols used in this study were approved by the Institutional Animal Ethics Committee (IAEC).

\subsection{Qualitative phytochemical analysis}

Aqueous extract of Moringa oleifera leaves (AEMO) was subjected to qualitative phytochemical screening for presence of phytoconstituent in accordance with the standard protocol. ${ }^{10}$

\subsection{Quantitative phytochemical estimation}

\subsubsection{Total phenolic content}

The total phenolic content was determined by using FolinCiocalteu assay. An aliquot $(1 \mathrm{ml})$ of extracts or standard solution of gallic acid $(20,40,60,80$ and $100 \mathrm{mg} / \mathrm{l})$ was added to $25 \mathrm{ml}$ volumetric flask, containing $9 \mathrm{ml}$ of distilled water. $1 \mathrm{ml}$ of Folin-Ciocalteu's phenol reagent was added to mixture and shaken. After $5 \mathrm{~min}, 10 \mathrm{ml}$ of $7 \% \mathrm{Na}_{2} \mathrm{CO}_{3}$ solution was added to the mixture. The solution was diluted to $25 \mathrm{ml}$ with distilled water and mixed. After incubation for $90 \mathrm{~min}$, absorbance against prepared reagent blank was determined at $750 \mathrm{~nm}$ with UV-Vis spectrophotometer. All samples were analyzed in triplicates. ${ }^{11}$

\subsubsection{Total flavonoid content}

Total flavonoid content was measured by the aluminum chloride colorimetric assay. An aliquot $(1 \mathrm{ml})$ of extracts (10 mg/100 ml of alkaline methanol) or standard solution of chrysin $(20,40,60,80$ and $100 \mathrm{mg} / \mathrm{l})$ was added to $10 \mathrm{ml}$ volumetric flask containing $4 \mathrm{ml}$ of $\mathrm{dd} \mathrm{H}_{2} \mathrm{O}$. To the flask was added $0.3 \mathrm{ml} 5 \% \mathrm{NaNO}_{2}$. After $5 \mathrm{~min}, 0.3 \mathrm{ml} 10 \% \mathrm{AlCl}_{3}$ was added. At 6 th $\mathrm{min}, 2 \mathrm{ml} 1 \mathrm{M} \mathrm{NaOH}$ was added, and the total volume was made up to $10 \mathrm{ml}$ with dd $\mathrm{H}_{2} \mathrm{O}$. The solution was mixed well, and the absorbance was measured against 
prepared reagent blank at $510 \mathrm{~nm}$. Samples were analyzed in triplicate. $^{11}$

\subsubsection{Total alkaloid content}

Accurately measured aliquots $(0.4,0.6,0.8,1$ and $1.2 \mathrm{ml})$ of atropine standard solution and $1 \mathrm{ml}$ of AEMO were transferred each to different separating funnels. To it, $5 \mathrm{ml} \mathrm{pH} 4.7$ phosphate buffer and $5 \mathrm{ml}$ Bromocresol green solution was added and shaken with 1, 2, 3 and $4 \mathrm{ml}$ of chloroform. The extracts were collected in a $10 \mathrm{ml}$ volumetric flask and then diluted to adjust volume with chloroform. The absorbance of the complex in chloroform was measured at $470 \mathrm{~nm}$ against blank prepared as above but without atropine. ${ }^{12}$

\subsection{Pharmacological study}

\subsubsection{Anxiolytic activity}

2.7.1.1. Elevated plus maze test (EPM). The elevated plus maze (EPM) consisted of two open arms $(16 \mathrm{~cm} \times 5 \mathrm{~cm})$ crossed with two closed arms $(16 \mathrm{~cm} \times 5 \mathrm{~cm} \times 12 \mathrm{~cm})$. The arms were connected by a central square of $5 \mathrm{~cm} \times 5 \mathrm{~cm}$. The maze was elevated to a height of $25 \mathrm{~cm}$ and placed inside a light and sound attenuated room. Groups of mice each containing six animals were treated with vehicle, diazepam $(1 \mathrm{mg} / \mathrm{kg})$ and $\operatorname{AEMO}(250,375$ and $500 \mathrm{mg} / \mathrm{kg})$. After $30 \mathrm{~min}$, mice were placed individually in the EPM, facing a closed arm. The time spent in open arm and closed arm, and entries into open and closed arms, were recorded for a period of $5 \mathrm{~min} .{ }^{13}$

2.7.1.2. Light/dark exploration test. In this test, two wooden boxes $(45 \mathrm{~cm} \times 27 \mathrm{~cm} \times 27 \mathrm{~cm})$ of dimensions attached to each other were used. One box was made dark by covering with plywood and other was illuminated with $60 \mathrm{~W}$ Lamp hung $25 \mathrm{~cm}$ above. The mice were administered Vehicle $(5 \mathrm{mg} / \mathrm{kg})$, Diazepam (1 mg/kg), AEMO (250, 375 and $500 \mathrm{mg} / \mathrm{kg}) 30 \mathrm{~min}$ before test. The mice were individually placed in center of the light box and observed for $5 \mathrm{~min}$. Time spent in light and dark box were measured. ${ }^{13}$

2.7.1.3. Hole board apparatus test. Mice were placed in a black Perspex box ( $50 \mathrm{~cm} \times 50 \mathrm{~cm}$, walls $30 \mathrm{~cm}$ high) with 16 equally spaced holes ( $2.5 \mathrm{~cm}$ diameter, $10 \mathrm{~cm}$ apart from each other) in the floor, and the box was raised to a height of $25 \mathrm{~cm}$ from the ground. Mice were treated with Vehicle $(5 \mathrm{mg} / \mathrm{kg})$, Diazepam $(1 \mathrm{mg} / \mathrm{kg})$, and AEMO (250, 375 and $500 \mathrm{mg} / \mathrm{kg}) 30 \mathrm{~min}$ before carrying out the test. The number of head poking was recorded for $5 \min ^{13}$

\subsubsection{Antiepileptic activity}

2.7.2.1. Pentylenetetrazole induced seizure. Mice of either sex were used. Animals were divided into 5 groups. Mice were treated with Vehicle ( $5 \mathrm{ml} / \mathrm{kg})$, Diazepam (1 mg/kg), and AEMO $(250,375$ and $500 \mathrm{mg} / \mathrm{kg}$ ) intraperitoneally. After $30 \mathrm{~min}$, PTZ ( $80 \mathrm{mg} / \mathrm{kg}$ ) was injected subcutaneously. The animals were observed for onset of seizure up to $30 \mathrm{~min}$ after PTZ administration and duration of seizure was measured. ${ }^{13}$

2.7.2.2. Maximum electroshock induced seizure. Swiss albino mice were used. Mice were divided into 5 groups of 6 each. Mice were treated with Vehicle $(5 \mathrm{ml} / \mathrm{kg})$, Phenytoin $(25 \mathrm{mg} / \mathrm{kg})$, and
AEMO (250, 375 and $500 \mathrm{mg} / \mathrm{kg}$ ) intraperitoneally. An electric shock (21 mA, for $0.2 \mathrm{~s}$ ) was applied to each animal using corneal electrode and duration of tonic hind leg extension was recorded. ${ }^{14}$

\subsection{Mechanistic study}

\subsubsection{Baclofen induced catatonia}

Mice were divided in groups of six. Mice were treated with vehicle or AEMO $(250,375$ and $500 \mathrm{mg} / \mathrm{kg}) 30 \mathrm{~min}$ before baclofen $(5 \mathrm{mg} / \mathrm{kg})$ and their forepaws were placed on a bar (placed $2.5 \mathrm{~cm}$ above the table) and the duration of catatonia (the time for which the animal maintains the imposed posture) was measured at 5, 15, 30, 60, 90, 120 min intervals. $^{15,16}$

\subsection{Statistical analysis}

All the values were given as means \pm S.E.M. Values were analyzed by one-way ANOVA, followed by Dunnett's test using Graph pad prism software for Windows.

\section{Results}

\subsection{Qualitative phytochemical screening}

The preliminary phytochemical screening of AEMO showed presence of tannins, proteins, glycosides, alkaloids, flavonoids, volatile oil, and phenolic compounds.

\subsection{Quantitative phytochemical estimation}

\subsubsection{Total phenolic content determination}

A linear calibration curve of gallic acid, in the range of $0-100 \mathrm{mg} / \mathrm{l}$ with coefficient of correlation $\left(r^{2}\right)$ value of 0.992 , was obtained using Folin-Ciocalteu method (Fig. 1). Total phenolic content of AEMO was found to be $37.91 \mathrm{mg}$ gallic acid equivalent/100 g of dry weight (Table 1).

\subsubsection{Total flavonoid content determination}

A linear calibration curve of chrysin, in the range of 0-100 mg/l with coefficient of correlation $\left(r^{2}\right)$ value of

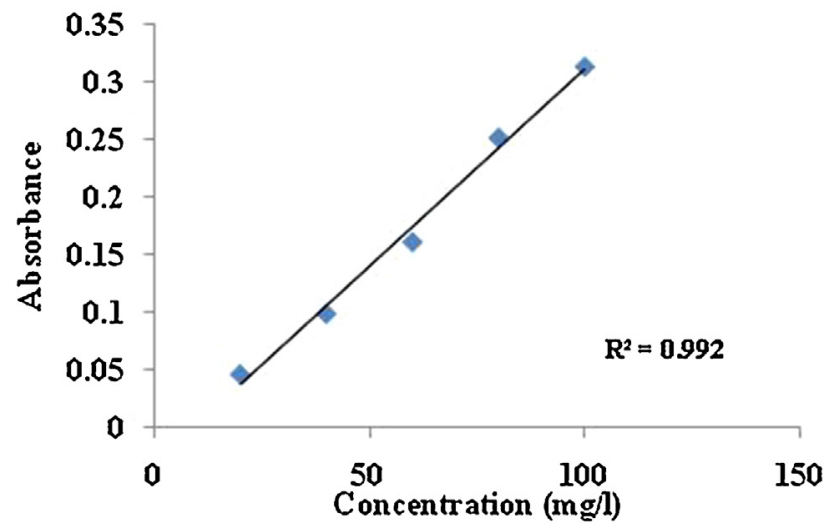

Fig. 1 - Calibration curve of standard gallic acid for determination of total phenolic content. 


\begin{tabular}{|c|c|c|c|}
\hline Extract & $\begin{array}{l}\text { Total phenolic } \\
\text { (mg GAE/100 g } \\
\text { of dry weight) }\end{array}$ & $\begin{array}{l}\text { Total flavonoid } \\
\text { (mg CE/100 g } \\
\text { of dry weight) }\end{array}$ & $\begin{array}{l}\text { Total alkaloid } \\
\text { (mg AE/100 g } \\
\text { of dry weight) }\end{array}$ \\
\hline AEMO & 37.91 & 63.25 & 91.25 \\
\hline
\end{tabular}

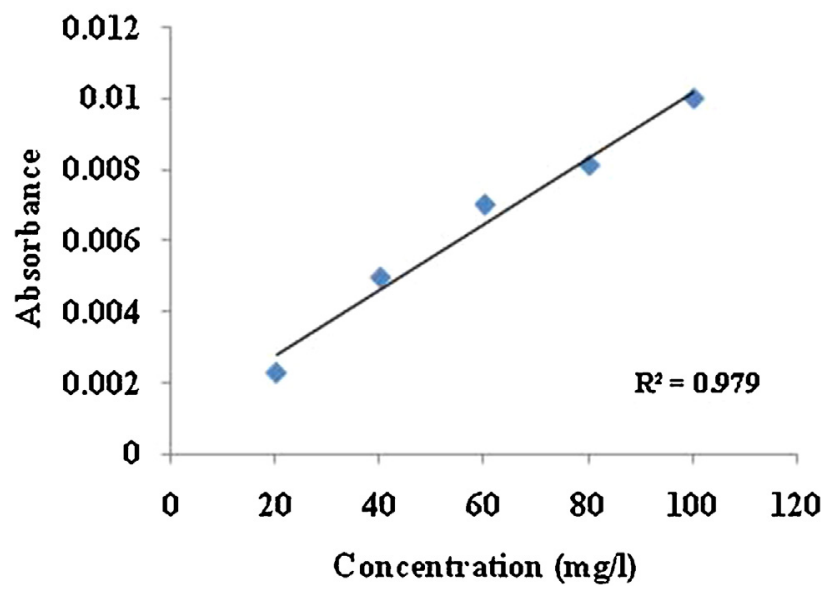

Fig. 2 - Calibration curve of standard chrysin for determination of total flavonoid content.

0.9796, was obtained using aluminum chloride colorimetric method (Fig. 2). Total flavonoid content of AEMO was found to be $63.25 \mathrm{mg}$ chrysin equivalent/100 g of dry weight (Table 1).

\subsubsection{Total alkaloid content}

A linear calibration curve of atropine, in the range of 0-120 mg/l with coefficient of correlation $\left(r^{2}\right)$ value of 0.9804 , was obtained Folin-Ciocalteu method (Fig. 3). Total alkaloid content of AEMO was found to be $91.25 \mathrm{mg}$ atropine equivalent/100 g of dry weight (Table 1).

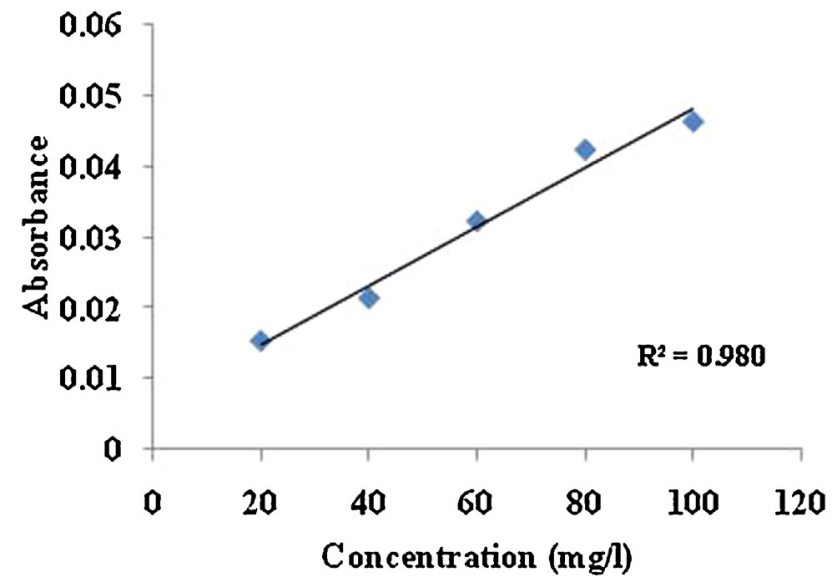

Fig. 3 - Calibration curve of standard atropine for determination of total alkaloid content.

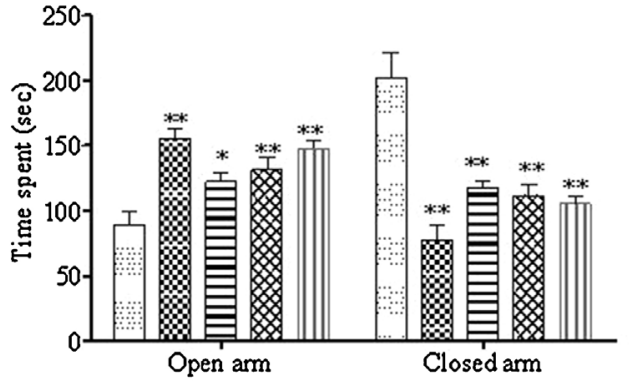

Vehicle $\otimes$ Diazepam $\boxminus$ AEMO-250 AEMO-375 II AEMO-500

Fig. 4 - Effect of AEMO on time spent in open and closed arm in elevated plus maze test; ${ }^{*} P<0.05,{ }^{* *} P<0.01$ compared with vehicle treated group (ANOVA is followed by Dunnett's test).

\subsection{Anxiolytic activity}

Antiepileptic activity was evaluated using pentylenetetrazole (PTZ) induced seizure and maximum electroshock (MES) induced seizure test. In PTZ test, treatment with AEMO at doses of 250, 375 and $500 \mathrm{mg} / \mathrm{kg}$ significantly $(P<0.01)$ delayed the onset of seizures and decreased the duration of seizures significantly $(P<0.01)$ in dose dependent manner compared to vehicle treated group. Treatment with AEMO at doses of 250, 375 and $500 \mathrm{mg} / \mathrm{kg}$ showed significant protection against PTZ induced seizure compared to the vehicle treated group. Animal treated with Diazepam (1 mg/kg, i.p.) showed 100\% protection against PTZ induced seizures (Figs. 8 and 9). In MES test, treatment with AEMO at doses of 250,375 and $500 \mathrm{mg} / \mathrm{kg}$ significantly $(P<0.01)$ reduced the duration of tonic hind leg extension as compared to vehicle treated group. The observations are given in Fig. 10. Thus, the results of MES test and PTZ test confirmed antiepileptic potential of AEMO in experimental animals.

Anxiolytic activity was evaluated using elevated plus maze, light/dark box and hole board test. In EPM, Diazepam $(1 \mathrm{mg} / \mathrm{kg}$, i.p.) increased the number of entries and the time spent in the open arms significantly $(P<0.01)$ compared to vehicle treated group. Animals treated with AEMO at doses of $250 \mathrm{mg} / \mathrm{kg}$ showed significant $(P<0.05)$ increase in the time spent in the open arms with no significant effect on number of entries. However, treatment with AEMO (375 and $500 \mathrm{mg} / \mathrm{kg}$ ) showed a significant $(P<0.05)$ increase in the time spent as well as number of entries in the open arm compared to vehicle treated group (Figs. 4 and 5).

In light/dark box model, Diazepam (1 mg/kg, i.p.) increased the time spent in the light chamber significantly $(P<0.01)$ compared to vehicle treated group. Animals treated with AEMO at doses of 250,375 and $500 \mathrm{mg} / \mathrm{kg}$ also showed a significant increase in the time spent in the light chamber $(P<0.01)$ compared to vehicle treated group (Fig. 6). In hole board test, Diazepam (1 mg/kg, i.p.) significantly increased numbers of head poking $(P<0.01)$ compared to the vehicle treated group. Treatment with AEMO $(250 \mathrm{mg} / \mathrm{kg})$ increased numbers of head poking significantly $(P<0.05)$ compared with the vehicle treated group. While treatment with AEMO 


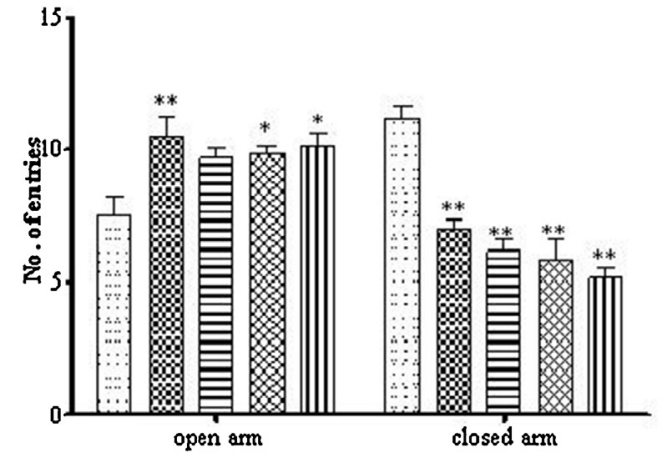

Vericle Diazepam $\boxminus$ AEMO-250 AEMO-375 向 AEMO-500

Fig. 5 - Effect of AEMO on number of entries in open and closed arm in elevated plus maze test; ${ }^{*} \mathrm{P}<0.05,{ }^{* *} \mathrm{P}<0.01$ compared with vehicle treated group (ANOVA is followed by Dunnett's test).

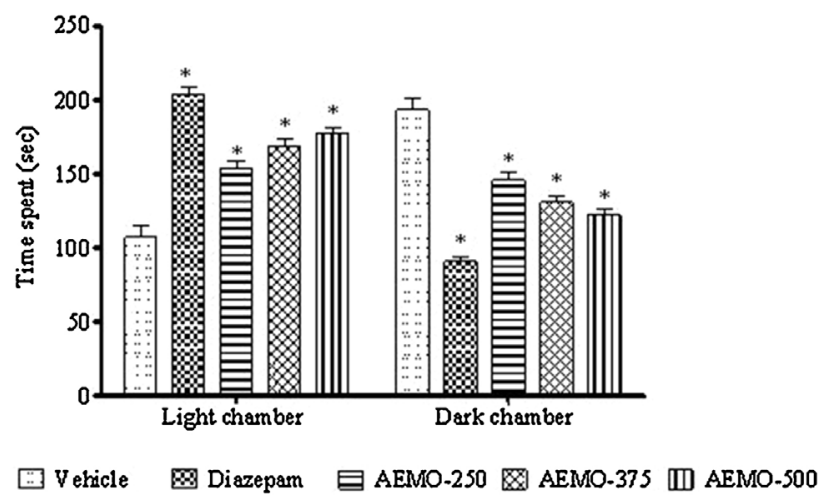

Fig. 6 - Effect of AEMO on time spent in light and dark box; ${ }^{*} \mathrm{P}<0.01$ compared with the vehicle treated group (ANOVA is followed by Dunnett's test).

(375 and $500 \mathrm{mg} / \mathrm{kg}$ ) increased numbers of head poking significantly $(P<0.01)$ compared with the vehicle treated group (Fig. 7). Thus, the results of elevated plus maze, light/ dark box and hole board test revealed that AEMO possess significant anxiolytic effect.

Further to elucidate mechanism of action, effect of AEMO on Baclofen induced catatonia was studied. In mechanistic study, Baclofen ( $5 \mathrm{mg} / \mathrm{kg}$, i.p.) induced significant catatonic effect in animals. Pretreatment with AEMO (250, 375 and $500 \mathrm{mg} / \mathrm{kg}$, i.p.) also induced catatonic effect. In addition, pretreatment with AEMO (250, 375 and $500 \mathrm{mg} / \mathrm{kg}$, i.p.) preponed catatonic effect significantly $(P<0.01)$ at $30 \mathrm{~min}$ interval (Fig. 11).

\section{Discussion}

From earliest times known to man, medicinal plants are considered as readily available, economical, and effective medication sources. People tend to rely on traditional and other forms of complementary and alternative medicine for chronic conditions, which do not respond well to conventional

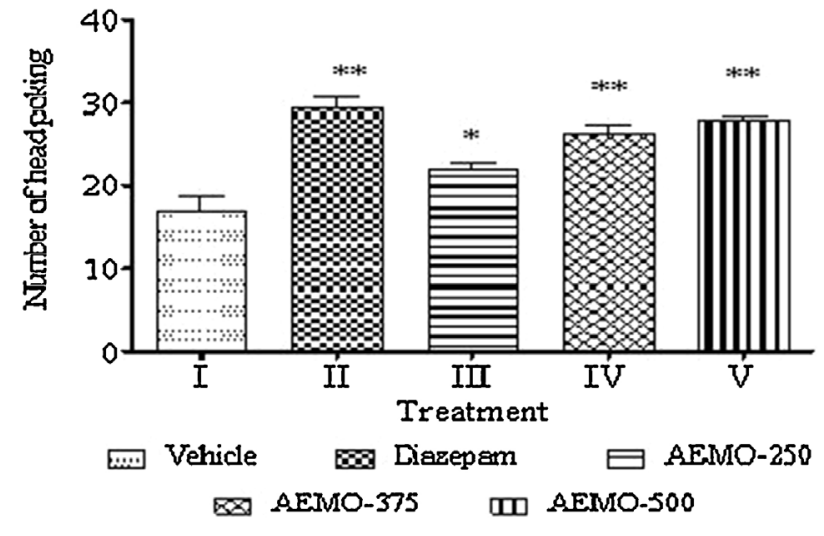

Fig. 7 - Effect of AEMO on number of head poking in hole board test; ${ }^{*} \mathrm{P}<0.05,{ }^{* *} \mathrm{P}<0.01$ compared with vehicle treated group (ANOVA is followed by Dunnett's test).

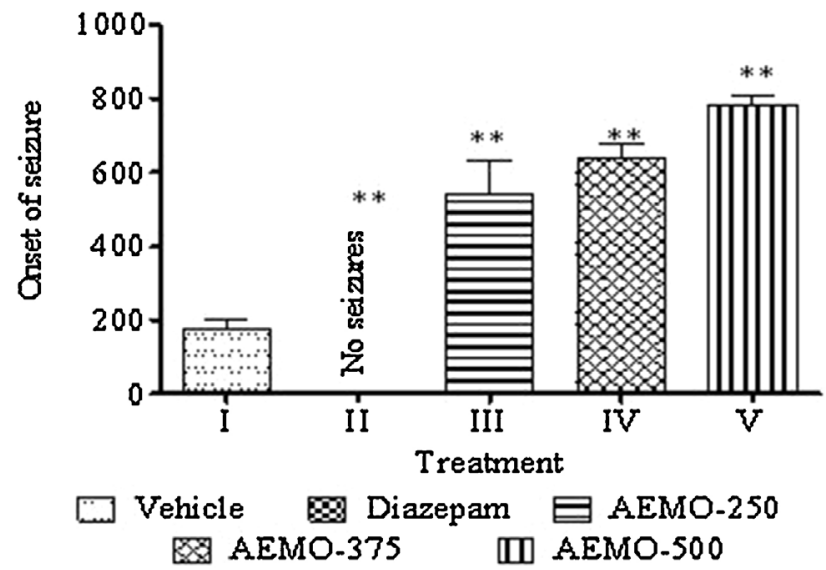

Fig. 8 - Effect of AEMO on onset of seizure in pentylenetetrazole induced seizure test; ${ }^{* *} P<0.01$ compared with vehicle treated group (ANOVA is followed by Dunnett's test).

or modern drug treatments. Among these are neurological disorders such as epilepsy, anxiety, and pain. ${ }^{17}$ They provide an effective alternative to modern medicine. Thus, pharmacological evaluation and standardization of such medicinal plants are the need of an hour. ${ }^{18} \mathrm{M}$. oleifera has been claimed to be traditionally useful in the treatment of epilepsy and anxiety. Hence, considering the need for medicinal plants as alternative to modern medicine and traditional claim about M. oleifera in treatment of epilepsy and anxiety, the present study was designed to study antiepileptic and anxiolytic activities of AEMO using various behavioral animal models.

The first important investigational step in the discovery of potential antiepileptic drug (AED) is the classical maximal electroshock (MES) test in mice. ${ }^{19}$ The MES test is the most commonly used animal model in AED discovery, because seizure induction is simple and the success rate for detecting clinically effective AEDs is high. AEDs such as phenytoin, carbamazepine, and valproic acid inhibit maximal electroshock induced hind limb tonic extension and are therefore 


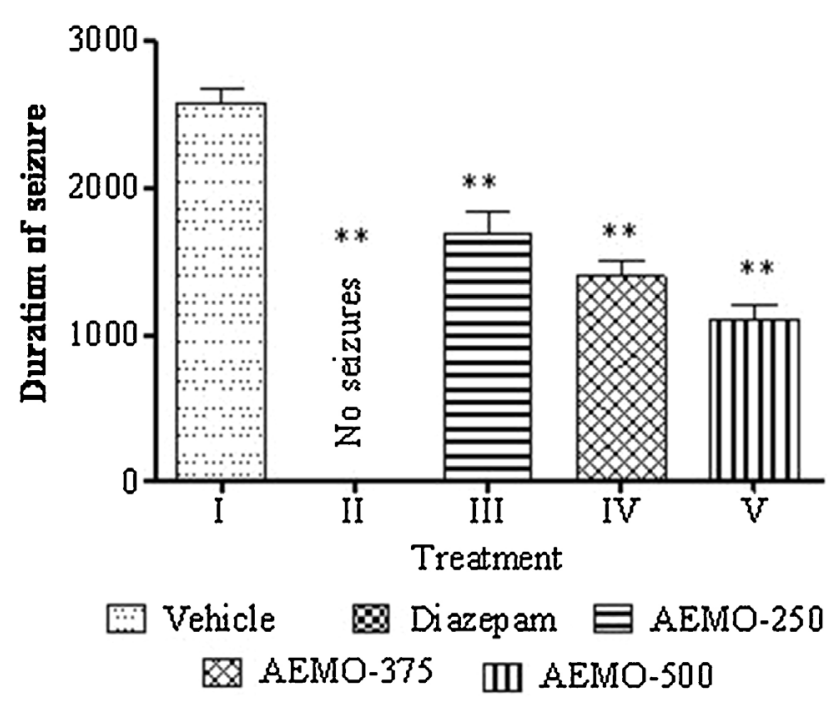

Fig. 9 - Effect of AEMO on duration of seizure in pentylenetetrazole induced seizure test; ${ }^{*} \mathrm{P}<0.01$ compared with vehicle treated group (ANOVA is followed by Dunnett's test).

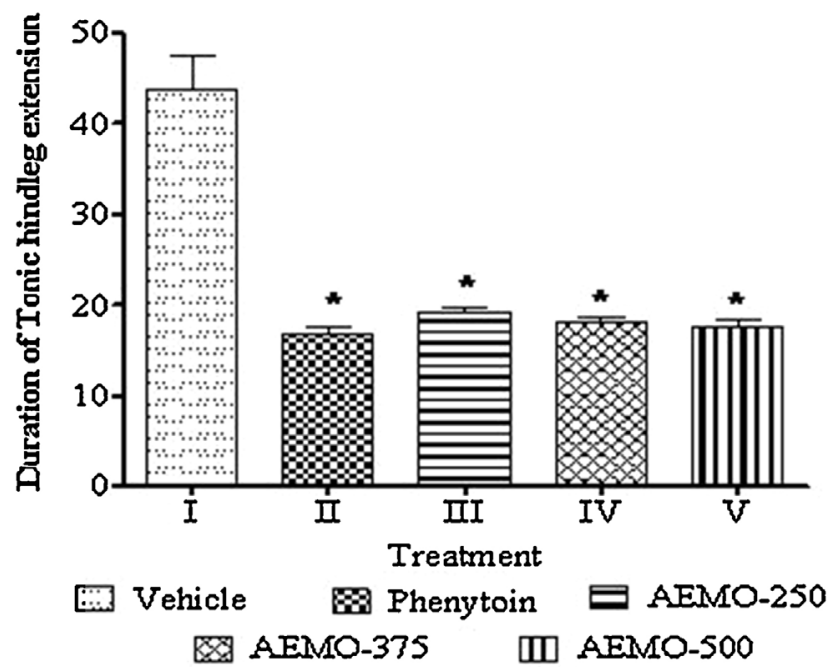

Fig. 10 - Effect of AEMO on maximum electroshock induced seizure test; ${ }^{*} P<0.01$ compared with vehicle treated group (ANOVA is followed by Dunnett's test).

effective in the treatment of generalized tonic-clonic and partial seizures. ${ }^{20}$ AED discovery is further guaranteed, when the MES test is followed by PTZ test. AEDs such as ethosuximide and phenobarbitone inhibit PTZ induced seizures and are effective in the treatment of generalized myoclonic and absence seizures. These are the two most important screening procedures employed in AED discovery. ${ }^{21-24}$ In present study, mice treated with AEMO (250, 375 and $500 \mathrm{mg} / \mathrm{kg}$, i.p.) significantly protected animals from MES and PTZ induced seizures. This result showed that AEMO possess significant antiepileptic activity and may be useful in treatment of grandmal and petitmal epilepsy.

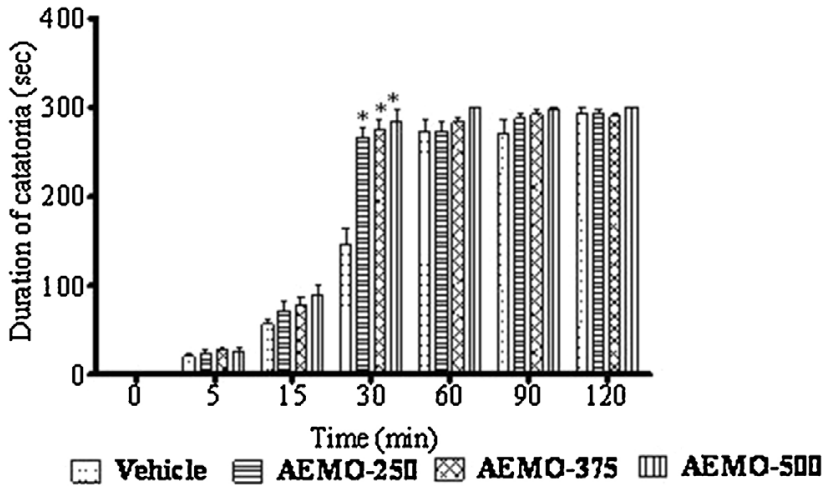

Fig. 11 - Effect of AEMO on baclofen induced catatonia; ${ }^{*} \mathrm{P}<0.01$ vs control (ANOVA followed by Dunnett's test).

The anxiolytic activity of AEMO was evaluated using elevated plus maze, light/dark box and hole board test. EPM is a well-established animal model for testing anxiolytic drugs. In this test, number of entries and time spent in open arms has generally been used as indicator of anxiety, with anxiolytics generally increasing and anxiogenics decreasing these measures. ${ }^{25}$ In the present study, treatment with AEMO (250, 375 and $500 \mathrm{mg} / \mathrm{kg}$, i.p.) significantly increased number of entries in the open arm as well as time spent in open arm, indicating an anxiolytic effect.

The light/dark box test is another simple behavior model in mice to detect compounds with anxiolytic effects. The light/ dark box test is based on rodent's natural dislike to bright areas compared to dark areas and their innate exploratory behavior. ${ }^{26}$ When mice are placed in the light/dark box, clinically effective anxiolytics have been shown to increase time spent in brightly lit and open area compared to dark compartment. ${ }^{27,28}$ In the present study, AEMO $(250,375$ and $500 \mathrm{mg} / \mathrm{kg}$, i.p.) showed significant increase in the time spent in the light box, suggesting anxiolytic action of AEMO.

The hole-board test provides a simple method for measuring the response of an animal to an unknown environment and is widely used to assess emotionality, anxiety, and/or responses to stress in animals. Head-dipping behavior is sensitive to changes in the emotional state of the animal. ${ }^{25}$ It has been suggested that anxiolytic drugs increases headdipping behavior. In the present study, AEMO at doses of (250, 375 and $500 \mathrm{mg} / \mathrm{kg}$, i.p.) significantly increased number of head-dipping. This indicates that AEMO possess significant anxiolytic activity.

It has been demonstrated that when the balance between excitatory and inhibitory neurotransmitter activities is shifted pharmacologically in favor of GABAergic transmission, anxiolytic effect is induced. On the other hand, an inhibition of the GABAergic system results in anxiety, restlessness, and even epileptic seizures. These pharmacological findings point to the contribution of inhibitory neurotransmitter GABA to the pathophysiology of brain disorders like anxiety disorders, epilepsy, and schizophrenia. ${ }^{29}$ Several AEDs exert their effects by actions on the GABAergic system. For e.g. Barbiturates exerts its pharmacological effects by allosteric activation of the $\mathrm{GABA}_{\mathrm{A}}$ receptor, increasing the duration of $\mathrm{Cl}$ channel 
opening, BZDs bind to the $\mathrm{GABA}_{\mathrm{A}}$ receptor increasing the frequency of $\mathrm{Cl}$ channel opening, Vigabatrin exert its antiepileptic effects by inhibition of GABA-T, the enzyme responsible for the catabolism of GABA thereby elevating GABA levels and potentiating inhibitory neurotransmission throughout the brain, Tiagabine exert its antiepileptic effects by inhibiting GABA uptake into synaptosomal membranes, neurones, and glial cells. ${ }^{30}$ Also, the role of the inhibitory neurotransmitter GABA has long been regarded as central to the regulation of anxiety, and this neurotransmitter system is the target of benzodiazepines and related drugs used to treat anxiety disorders. ${ }^{31}$ These evidences suggest a prominent role of GABA in anxiety and epileptic disorder. This made us to find out the involvement of GABA in anxiolytic and antiepileptic activity of AEMO. In an attempt to do so, we evaluated effect of AEMO on Baclofen induced catatonia, a GABA mediated behavior. Baclofen is structurally similar to inhibitory neurotransmitter GABA and stimulates GABA receptors and induces catatonia. GABA mimetic agent potentiates and GABA antagonist inhibits Baclofen induced catatonia (Kasture et al., 1996). In present study, AEMO (250, 375 and $500 \mathrm{mg} / \mathrm{kg}$, i.p.) significantly potentiated (preponed) Baclofen induced catatonia, which is suggestive of its GABA mimetic action.

Further, it has been known that most of flavonoid (apigenin and chrysin) interacts with $\mathrm{GABA}_{\mathrm{A}}$-receptor producing sedation, anxiolytic or anticonvulsive effects. ${ }^{32}$ Quantitative phytochemical investigation of AEMO revealed presence of substantial amount of flavonoids. Therefore, it could be concluded from the results that AEMO possess significant antiepileptic and anxiolytic activity, which is probably mediated through its GABA mimetic action. Thus, AEMO can be a good alternative to treatment of anxiety in patients of epilepsy to improve their quality of life.

\section{Conclusion}

In conclusion, aqueous extract of $M$. oleifera possess anxiolytic and antiepileptic effects possibly mediated via of GABA mimetic action and these findings authenticate the traditional claims about use of $\mathrm{M}$. oleifera in treatment of epilepsy and anxiety. The isolation of active constituents from this plant might serve as lead for the development of drugs, which could be a good alternative to treatment of anxiety in patients of epilepsy to improve their quality of life.

\section{Conflicts of interest}

All authors have none to declare.

\section{Acknowledgements}

The authors are thankful to the Management of SCES's Indira College of Pharmacy, Pune-411033, Maharashtra, India for providing laboratory and library facilities for research work.

\section{R E F E R E N C E S}

1. Barragán E. Epilepsy and related psychiatric conditions. In: Rey JM, ed. In: IACAPAP e-Textbook of Child and Adolescent Mental Health. Geneva: International Association for Child and Adolescent Psychiatry and Allied Professions; 2012-12.

2. Ozalp E. Anxiety disorders in epilepsy. In: Szirmai Ãtl, ed. In: Anxiety Related Disorders. Europe: InTech; 2011. Available from: http://www.intechopen.com/books/anxiety-andrelateddisorders/anxiety-disorders-in-epilepsy.

3. Kulkarni SK, Reddy DS. Animal behavioral models for testing anti-anxiety agents. Methods Find Exp Clin Pharmacol. 1996;18:219-230.

4. Yadav AV, Kawale LA, Nade VS. Effect of Morus alba L. (mulberry) leaves on anxiety in mice. Ind J Pharmacol. 2008;40:32-36.

5. Milutin N, Miroslava J, Sreten V, Nenad N, Periša S. Anxiety in epileptic patients. Psychiatria Danubina. 2011;23:264-269.

6. Goyal BR, Agarwal BB, Goyal RK, Mehta A. Phytopharmacology of Moringa oleifera Lam: an overview. Nat Prod Rediance. 2007;6:347-353.

7. Mishra G, Singh P, Verma R, Kumar S, Shrivastav S, Khosa RL. Traditional uses, phytochemistry and pharmacological properties of Moringa oleifera plant: an overview. Der Pharmacia Lettre. 2011;3:141-164.

8. Khawaja TM, Tahira M, Ikram UH. Moringa oleifera: a natural gift - a review. J Pharm Sci Res. 2010;2:775-781.

9. Bakre AG, Aderibigbe AO, Ademowo OG. Studies on neuropharmacological profile of ethanol extract of Moringa oleifera leaves in mice. J Ethnopharmacol. 2013;149:783-789.

10. Harborne JB. In: Jackman H, ed. In: Phytochemical Methods. 1973; 70. London.

11. Marinova D, Ribarova F, Atanassova M. Total phenolics and total flavonoids in Bulgarian fruits and vegetables. J Univ Chem Technol Metall. 2005;40:255-260.

12. Shamsa F, Monsef HR, Ghamooshi R, Verdian R, Mohammad R. Spectrophotometric determination of total alkaloids in Peganum harmala L. using bromocresol green. Res J Phytochem. 2007;1:79-82.

13. Jain NN, Ohal CC, Shroff RH, Somani RS, Kasture VS, Kasture SB. Clitorea ternatea and the CNS. Pharmacol Biochem Behav. 2003;75:529.

14. Swinyard EA, Brown WC, Goodman LS. Comparative assays of antiepileptic drugs in mice and rats. J Pharmacol Exp Ther. 1952;106:319-330.

15. Kasture SB, Mandhane SN, Chopde CT. Baclofen induced catatonia: modification by serotonergic agents. Neuropharmacology. 1996;35:595-598.

16. Silva SR, Futuro-Neto HA, Pires JG. Effects of 5-HT3 receptor antagonists on neuroleptic-induced catalepsy in mice. Neuropharmacology. 1995;34:97-99.

17. Spinella M. herbal medicines and epilepsy: the potential for benefit and adverse effects. Epilepsy Behav. 2001;2:524-532.

18. Mahendran G, Thamotharan G, Sengottuvelu S, Narmatha Bai V. Evaluation of anticonvulsant, sedative, anxiolytic, and phytochemical profile of the methanol extract from the aerial parts of Swertia corymbosa (Griseb.) Wight ex C.B. Clarke. Biomed Res Int. 2014;2014:542385. http://dx.doi.org/ 10.1155/2014/542385.

19. Putnam TJ, Merritt HH. Experimental determination of the anticonvulsant properties of some phenyl derivatives. Science. 1937;85:525-526.

20. Loscher W. Animal models of epilepsy for the development of antiepileptogenic and disease-modifying drugs. A comparison of the pharmacology of kindling and poststatus epilepticus models of temporal lobe epilepsy. Epilepsy Res. 2002;50:105-123. 
21. Krall RL, Penry JK, White BG, Kupferberg HJ, Swinyard EA. Antiepileptic drug development: II. Anticonvulsant drug screening. Epilepsia. 1978;19:409-428.

22. Loscher W, Honack D, Rundfeldt C. Antiepileptogenic effects of the novel anticonvulsant levetiracetam (ucb L059) in the kindling model of temporal lobe epilepsy. J Pharmacol Exp Ther. 1998;284:474-479.

23. Raza M, Shaheen F, Choudhary MI, et al. Anticonvulsant activities of ethanolic extract and aqueous fraction isolated from Delphinium denudatum. J Ethnopharmacol. 2001;78:73-78.

24. White HS. Clinical significance of animal seizure models and mechanism of action studies of potential antiepileptic drugs. Epilepsia. 1997;38:S9-S17.

25. File SE, Lippa AS, Beer B, Lippa MT. Animal tests of anxiety. Curr Protoc Neurosci. 2004. Chapter 8: Unit 8.3.

26. Crawley JN. Exploratory behavior models of anxiety in mice. Neurosci Biobehav Rev. 1985;9:37-44.
27. Shimada T, Matsumoto K, Osanai M, Matsuda H, Terasawa $\mathrm{K}$, Watanabe $\mathrm{H}$. The modified light/dark transition test in mice: evaluation of classic and putative anxiolytic and anxiogenic drugs. Gen Pharmacol. 1995;26:205-210.

28. Wei XY, Yang JY, Wang JH, Wu CF. Anxiolytic effect of saponins from Panax quinquefolium in mice. J Ethnopharmacol. 2007;111:613-618.

29. Möhler H. GABA $A$ receptors in central nervous system disease: anxiety, epilepsy, and insomnia. J Recept Signal Transduct. 2006;26:731-740.

30. Kwan 1 P, Sills GJ, Brodie MJ. The mechanisms of action of commonly used antiepileptic drugs. Pharmacol Therapeut. 2001;90:21-34

31. Nuss P. Anxiety disorders and GABA neurotransmission: a disturbance of modulation. Neuropsychiatr Dis Treat. 2015;11:165-175.

32. Jäger AK, Saaby L. Flavonoids and the CNS. Molecules. 2011;16:1471-1485. 